\title{
SIBLINGS WITH SHORT STATURE AND BRITTLE HAIR- MYSTERY UNVEILED
}

\author{
Arun Ganesh $C^{1}$, Sujitha P2, Ashvind ${ }^{3}$, Sujatha Sridharan 4
}

1 Postgraduate Student, Department of Paediatrics, Chettinad Academy of Research and Education, Kelambakkam, Tamilnadu. ${ }^{2}$ Assistant Professor, Department of Paediatrics, Chettinad Academy of Research and Education, Kelambakkam, Tamilnadu. ${ }_{3}^{3}$ Assistant Professor, Department of Paediatrics, Chettinad Academy of Research and Education, Kelambakkam, Tamilnadu. 4 Professor, Department of Paediatrics, Chettinad Academy of Research and Education, Kelambakkam, Tamilnadu.

HOW TO CITE THIS ARTICLE: Ganesh AC, Sujitha P, Ashvind, et al. Siblings with short stature and brittle hair- mystery unveiled. J. Evolution Med. Dent. Sci. 2018;7(13):1679-1680, DOI: 10.14260/jemds/2018/379

\section{PRESENTATION OF CASE}

Siblings (6 years and 9 years old/ female) born to 3rd degree consanguineously married couple from a village in Telangana presented to us with complaints of dry scaling of skin present all over the body since birth, short stature, brittle hair and delayed development.

Tay syndrome or trichothiodystrophy (TTD) is a very rare autosomal recessive disorder characterised by congenital ichthyosiform erythroderma and brittle sulphur-deficient hair. Other features include short stature, intellectual impairment, photosensitivity and multiple defects affecting organs mainly derived from neuroectoderm. Till date only less than 110 cases of Tay syndrome have been reported in literature worldwide and there are no cases of siblings with Tay syndrome reported in India till date. We present here a case of siblings from a South Indian family with Tay syndrome.

\section{CLINICAL FEATURES}

\begin{tabular}{|c|c|c|}
\hline & Child - A & Child - B \\
\hline Age/Sex & 9 yrs./ Female & 6 Years/ Female \\
\hline Weight & $\begin{array}{c}15 \text { kgs Expected } \\
\text { Weight - 32 kgs }\end{array}$ & $\begin{array}{c}11 \text { kgs Expected } \\
\text { Weight - } 21 \mathrm{kgs}\end{array}$ \\
\hline $\begin{array}{c}\text { Height } \\
\text { (Short Stature) }\end{array}$ & $\begin{array}{c}108 \mathrm{~cm} \text { Expected } \\
\text { Height - } 132 \mathrm{~cm}\end{array}$ & $\begin{array}{c}95 \mathrm{~cm} \text { Expected } \\
\text { Height - } 114 \mathrm{~cm}\end{array}$ \\
\hline Bone Age & 3 years & 2 years \\
\hline Skin Findings & $\begin{array}{c}\text { Ichthyosiform } \\
\text { Erythroderma }\end{array}$ & $\begin{array}{c}\text { Ichthyosiform } \\
\text { Erythroderma }\end{array}$ \\
\hline Hair & $\begin{array}{c}\text { Straight, Coarse, } \\
\text { Unruly and Brittle }\end{array}$ & Scarce and Brittle \\
\hline $\begin{array}{c}\text { IQ (Stanford- } \\
\text { Binet Scale) }\end{array}$ & 78 & 70 \\
\hline $\begin{array}{c}\text { Developmental } \\
\text { Age }\end{array}$ & 7 years & 4 years \\
\hline
\end{tabular}

\section{Birth History}

All 3 siblings were born at home and was delivered by a trained dhai. First sibling had ichthyosis at birth and died at day 5 of life at the hospital in view of sepsis. $2^{\text {nd }}$ and $3^{\text {rd }}$ sibling was taken to the hospital immediately after birth, as they too had ichthyosis at birth and was discharged at Day 10 of life with topical emollients.

'Financial or Other Competing Interest': None. Submission 17-02-2018, Peer Review 11-03-2018, Acceptance 19-03-2018, Published 26-03-2018.

Corresponding Author:

Dr. Arun Ganesh C,

\#67/1A, Greenpeace Apartments,

RK Shanmugam Salai, K. K. Nagar,

Chennai-600078, Tamilnadu.

E-mail:arun8591@gmail.com

DOI: $10.14260 /$ jemds $/ 2018 / 379$

\section{(c) (i) $(9)$}

\section{Family Pedigree Chart}

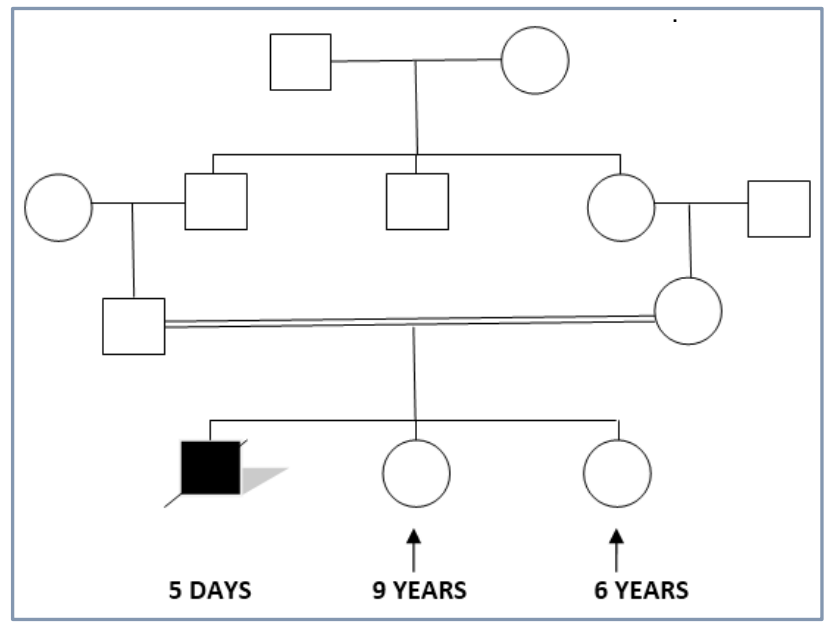

DIFFERENTIAL DIAGNOSES

With the above mentioned Clinical Features, 3 differential Diagnoses was Considered-

1. Netherton syndrome- characterised by ichthyosiform erythroderma, trichorrhexis invaginata and atopic diathesis.

2. Chanarin-Dorfman syndrome- characterised by congenital ichthyosis, lipid vacuoles in leucocytes and hepatomegaly.

3. Tay syndrome or trichothiodystrophy- congenital ichthyosiform erythroderma, brittle sulphur deficient hair, short stature and intellectual impairment.

\section{CLINICAL DIAGNOSIS}

Since both the siblings had intellectual impairment and short stature, the diagnosis of Tay syndrome was considered.

\section{FINAL DIAGNOSIS}

- Hair Shaft Examination under Polarising Microscopy Showed diagnostic alternating light and dark banding pattern called Tiger tail banding suggestive of Tay syndrome.

\section{- Biochemical Examination of Hair}

Chromatography of hair amino acids done revealed decreased sulphur containing amino acids, cysteine, proline and threonine thereby confirming the diagnosis. 


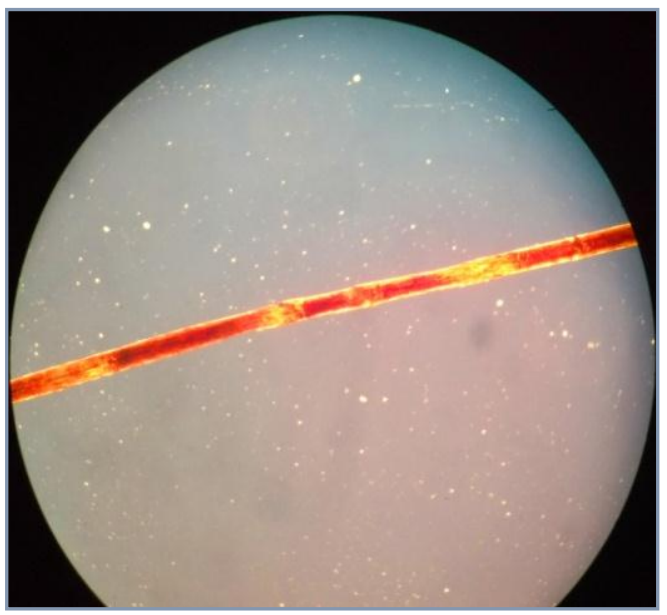

Figure A. Showing "Tiger Tail Banding" seen under Polarising Microscope

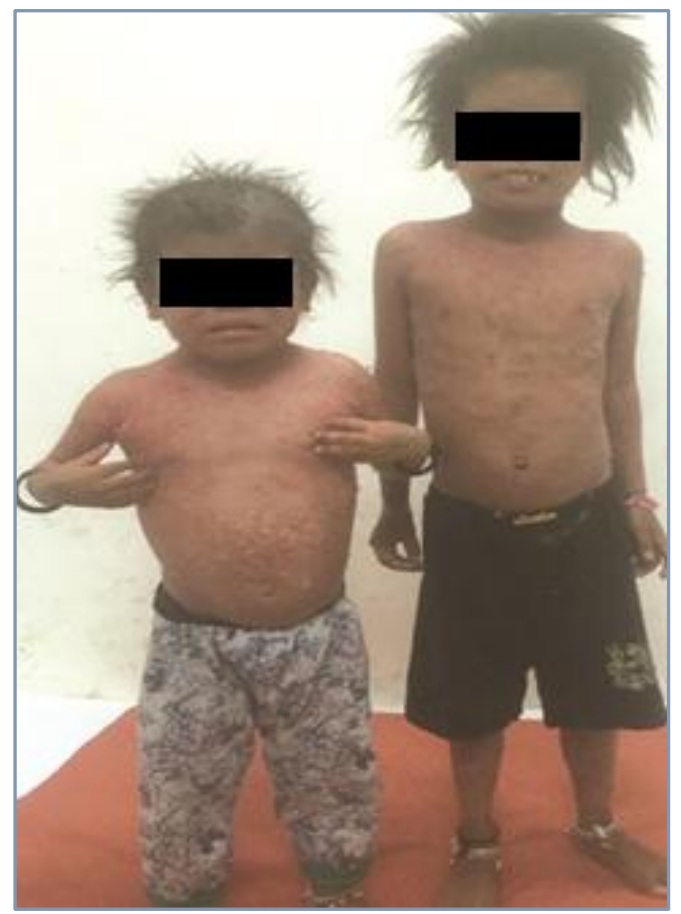

Figure B. Picture of Siblings with Tay Syndrome (Short Stature, Ichthyosis, Brittle and Sparse Hair)

\section{DISCUSSION OF MANAGEMENT}

Tay syndrome or Trichothiodystrophy is a very rare disease with autosomal recessive inheritance characterised by brittle, sulphur deficient hair. ${ }^{1,2}$ It is a multisystem disorder with a varied spectrum of clinical features. The common clinical features are brittle hair or hair shaft abnormalities (96\%), intellectual impairment (86\%), short stature $(73 \%)$ and ichthyosis (65\%). ${ }^{3}$ The name reflects the brittle, sulphur deficient hair seen in all TTD patients (From Greek- trichomeaning hair; -thio-, sulphur; -dys-, faulty; -trophy, nourishment). Various acronyms have been used to describe the clinical features of this syndrome. PIBIDS, ${ }^{4}$ IBIDS 5,6 and BIDS $^{7}$ describe the features of TTD: Photosensitivity, Ichthyosis, Brittle hair, Intellectual impairment, Decreased fertility and Short stature. In 1985, defective DNA excision repair in ultraviolet (UV) exposed lymphocytes by Van Neste ${ }^{8}$ from a TTD patient. Recently, in non-photosensitive patients TTDN1 gene with unknown function was identified. 8 Till date, four genes causing TTD have been identified: XPD, XPB, TTDA and TTDN 1.3

Diagnosis can be made by demonstration of Tiger tail banding in the hair shaft under polarising microscopy, which is diagnostic of and is seen exclusively in Tay syndrome. ${ }^{3}$ Hair shaft examination under scanning electron microscope reveals flat hair with trichoschisis and chromatography hair amino acids show decreased sulphur containing amino acids.

No specific treatment for Tay syndrome is available. Management is mainly symptomatic. Family psychological and social support is needed. Children should be advised to avoid sunlight exposure and aggressive combing or hair dressing due to weakness of hair shaft.

\section{CONCLUSION}

Tay syndrome should be considered as a differential diagnosis in any child with congenital ichthyosis and hair abnormalities. A simple hair shaft examination under polarised microscopy will help to clinch the diagnosis. We report this case for its rarity.

\section{REFERENCES}

[1] Itin PH, Sarasin A, Pittelkow MR. Trichothiodystrophy: update on the sulfur-deficient brittle hair syndromes. J Am Acad Dermatol 2001;44(6):891-920.

[2] Ruenger TM, DiGiovanna JJ, Kraemer KH. Hereditary diseases of genome instability and DNA repair. In: Wolff K, Goldsmith LA, Katz SI, et al. (eds). Fitzpatrick's dermatology in general medicine. $7^{\text {th }}$ edn. New York: McGraw Hill, 2008:1311-25.

[3] Faghri S, Tamura D, Kraemer KH, et al. Trichothiodystrophy: a systematic review of 112 published cases characterises a wide spectrum of clinical manifestations. J Med Genet 2008;45(10):60921.

[4] Crovato F, Borrone C, Rebora A. Trichothiodystrophy-BIDS, IBIDS and PIBIDS? Br J Dermatol 1983;108(2):247.

[5] Jorizzo JL, Crounse RG, Wheeler CE. Lamellar ichthyosis, dwarfism, mental retardation, and hair shaft abnormalities. A link between the ichthyosisassociated and BIDS syndromes. J Am Acad Dermatol 1980;2(4):309-17.

[6] Jorizzo JL, Atherton DJ, Crounse RG, et al. Ichthyosis, brittle hair, impaired intelligence, decreased fertility and short stature (IBIDS syndrome). $\mathrm{Br}$ J Dermatol 1982;106(6):705-10.

[7] Baden HP, Jackson CE, Weiss L, et al. The physicochemical properties of hair in the BIDS syndrome. Am J Hum Genet 1976;28(5):514-21.

[8] Van Neste D, Caulier B, Thomas P, et al. PIBIDS: Tay's syndrome and xeroderma pigmentosum. J Am Acad Dermatol 1985;12(2 Pt 1):372-3. 